\title{
Review \\ The Emerging Roles of Chromogranins and Derived Polypeptides in Atherosclerosis, Diabetes, and Coronary Heart Disease
}

\author{
Takuya Watanabe
}

check for updates

Citation: Watanabe, T. The Emerging Roles of Chromogranins and Derived Polypeptides in Atherosclerosis, Diabetes, and Coronary Heart Disease. Int. J. Mol. Sci. 2021, 22, 6118. https://doi.org/10.3390/ijms221 16118

Academic Editor: Michael Henein

Received: 18 April 2021

Accepted: 2 June 2021

Published: 6 June 2021

Publisher's Note: MDPI stays neutral with regard to jurisdictional claims in published maps and institutional affiliations.

Copyright: (C) 2021 by the author. Licensee MDPI, Basel, Switzerland. This article is an open access article distributed under the terms and conditions of the Creative Commons Attribution (CC BY) license (https:// creativecommons.org/licenses/by/ $4.0 /)$.
Department of Internal Medicine, Ushioda General Hospital/Clinic, Yokohama, Kanagawa 230-0001, Japan; watanabe_9721@yahoo.co.jp; Tel.: +81-45-521-5147; Fax: +81-45-503-1609

\begin{abstract}
Chromogranin A ( $\mathrm{CgA}), \mathrm{B}(\mathrm{CgB})$, and C ( $\mathrm{CgC})$, the family members of the granin glycoproteins, are associated with diabetes. These proteins are abundantly expressed in neurons, endocrine, and neuroendocrine cells. They are also present in other areas of the body. Patients with diabetic retinopathy have higher levels of $\mathrm{CgA}, \mathrm{CgB}$, and $\mathrm{CgC}$ in the vitreous humor. In addition, type 1 diabetic patients have high $\mathrm{CgA}$ and low $\mathrm{CgB}$ levels in the circulating blood. Plasma CgA levels are increased in patients with hypertension, coronary heart disease, and heart failure. $\mathrm{CgA}$ is the precursor to several functional peptides, including catestatin, vasostatin-1, vasostatin-2, pancreastatin, chromofungin, and many others. Catestatin, vasostain-1, and vasostatin-2 suppress the expression of vascular cell adhesion molecule- 1 and intercellular adhesion molecule- 1 in human vascular endothelial cells. Catestatin and vasostatin-1 suppress oxidized low-density lipoprotein-induced foam cell formation in human macrophages. Catestatin and vasostatin-2, but not vasostatin-1, suppress the proliferation and these three peptides suppress the migration in human vascular smooth muscles. Chronic infusion of catestatin, vasostatin-1, or vasostatin-2 suppresses the development of atherosclerosis of the aorta in apolipoprotein E-deficient mice. Catestatin, vasostatin-1, vasostatin-2, and chromofungin protect ischemia/reperfusion-induced myocardial dysfunction in rats. Since pancreastatin inhibits insulin secretion from pancreatic $\beta$-cells, and regulates glucose metabolism in liver and adipose tissues, pancreastatin inhibitor peptide-8 (PSTi8) improves insulin resistance and glucose homeostasis. Catestatin stimulates therapeutic angiogenesis in the mouse hind limb ischemia model. Gene therapy with secretoneurin, a $\mathrm{CgC}$-derived peptide, stimulates postischemic neovascularization in apolipoprotein E-deficient mice and streptozotocin-induced diabetic mice, and improves diabetic neuropathy in $\mathrm{db} / \mathrm{db}$ mice. Therefore, $\mathrm{CgA}$ is a biomarker for atherosclerosis, diabetes, hypertension, and coronary heart disease. $\mathrm{CgA}$ - and $\mathrm{CgC}$-derived polypeptides provide the therapeutic target for atherosclerosis and ischemia-induced tissue damages. PSTi8 is useful in the treatment of diabetes.
\end{abstract}

Keywords: chromogranins; catestatin; vasostatin; pancreastatin; secretoneurin; atherosclerosis; diabetes; hypertension; coronary heart disease

\section{Introduction}

Coronary heart disease is now the leading cause of death worldwide [1]. The risk factors for coronary heart disease involve hypercholesteremia, diabetes, hypertension, obesity, and metabolic syndrome [1]. Coronary heart disease exhibits myocardial ischemia and dysfunction induced by significant stenosis in coronary arteries that supply the heart with blood [1]. It is usually caused by atherosclerosis, which is a chronic inflammatory disease with a buildup of cholesterol-rich plaques inside the artery walls [1]. Atherosclerosis is characterized by a complex multicellular process [2], and is triggered by arterial injury-induced endothelial inflammation. This results in the formation of intimal atheroma and plaque caused by oxidized low-density lipoprotein (LDL)-induced macrophage foam 
cell formation, vascular smooth muscle cell (VSMC) proliferation, and extracellular matrix (ECM) production [2].

Chromogranin A $(\mathrm{CgA})$, chromogranin $\mathrm{B}(\mathrm{CgB})$, and chromogranin $\mathrm{C}(\mathrm{CgC})$, which are abundantly expressed in neurons, endocrine, and neuroendocrine cells, are associated with carbohydrate metabolism [3]. These proteins belong to a class of granins, which were first defined as proteins involved in the formation and function of secretory granules [4-6]. The other part of the name (chromo-) relates to the fact that chromaffin granules were the first discovered to contain granin proteins [7]. CgA is known to play a significant role in the pathogenesis and development of type 1 diabetes, and is associated with its complications [8-10]. A CgA-derived peptide, pancreatin, is expressed in the pancreatic islet [11], and has a strong inhibitory action on insulin secretion from the islet $\beta$-cells [12]. A pancreastatin inhibitor can cancel the diabetogenic effects of pancreastatin [13].

Previous studies have shown that genetic polymorphisms of $\mathrm{CgA}, \mathrm{CgB}$, and $\mathrm{CgC}$ are associated with hypertension [14-16]. A recent study suggests that a common genetic variant of the $\mathrm{CgA}$-derived peptide catestatin is associated with hypertension and atherogenesis $[17,18]$. In addition to catestatin, the other CgA-derived peptides, vasostatin-1 and vasostatin-2, exert atheroprotective effects [19-21]. Both catestatin and vasostatin-1 have vasorelaxant properties [22]. Vasoconstriction-inhibiting factor (VIF) suppresses angiotensin II-induced vasoconstriction [23]. Thereby, catestatin, vasostatin-1, and VIF have counter-regulatory effects against hypertension [22,23].

This review introduces the emerging roles of $\mathrm{CgA}, \mathrm{CgB}, \mathrm{CgC}$, and derived polypeptides in the multicellular pathogenesis and development of atherosclerosis, diabetes, and coronary heart disease. Using these proteins and polypeptides along with current challenges and advances in clinical practice, such as biomarker and therapeutic strategies for atherosclerotic cardiovascular diseases, will be discussed in this review.

\section{Characteristics of $\mathrm{CgA}, \mathrm{CgB}$, and $\mathrm{CgC}$}

Granins form a family of highly acidic proteins that are primarily found in the lumen of dense-core secretory granules of endocrine cells and neurons [24]. The most abundant members of this family are $\mathrm{CgA}, \mathrm{CgB}$ (also called secretogranin I), and $\mathrm{CgC}$ (also called secretogranin II) [3]. CgA was first isolated from chromaffin cells of the adrenal medulla [25], and $\mathrm{CgB}$ was initially characterized in a rat pheochromocytoma cell line [26]. $\mathrm{CgC}$ (secretogranin II) was independently discovered later, in the anterior pituitary and prostate cancer cells [27]. Human CHGA, CHGB, and SCG2 loci have been mapped to chromosomes 14q32.12, 20pter-p12, and 2q35-2q36, respectively [28]. Human CgA and human $\mathrm{CgB}$ consist of 457 and 677 amino acids with molecular weights of 51 and $78 \mathrm{kDa}$, respectively $[3,29,30]$. $\mathrm{CgA}$ and $\mathrm{CgB}$ contain a homologous, disulfide-bonded loop structure near their termini and another homologous sequence at C-termini $[29,31]$. Human $\mathrm{CgC}$ is composed of 617 amino acids with a molecular weight of $68 \mathrm{kDa}$ [3], and does not have the disulfide-bonded loop and the homologous C-terminal domain of CgA and $\mathrm{CgB}$ [32]. However, $\mathrm{CgC}$ contains a weak homology to the C-terminal region of $\mathrm{CgA}$ and $\mathrm{CgB}$ at a position of $\sim 120$ amino acid residues upstream from its $\mathrm{C}$ terminus [3]. When compared to genomic structures of $\mathrm{CgC}$ and $\mathrm{CgB}$, it appears that $\mathrm{CgC}$ as a whole (except for its 27 amino acid signal peptide) corresponds to exon 4 of $\mathrm{CgB}$ [3].

$\mathrm{CgA}, \mathrm{CgB}$, and $\mathrm{CgC}$ are characterized by the following: (1) an abundance of acidic amino acids, (2) calcium binding sites, (3) multiple potential dibasic cleavage sites, (4) a multitude of post-translational modifications, and (5) the tendency to self-aggregate at low $\mathrm{pH} /$ high calcium conditions typical of secretory granules [3].

Both $\mathrm{CgA}$ and $\mathrm{CgB}$ regulate both catecholamine levels and blood pressure [33]. They also have an effect on glucose and insulin metabolism [10,34]. CgC induces dopamine release from the striatum [35]. 


\section{Cgs-Derived Polypeptides}

CgA was identified as an acidic protein costored and coreleased with ATP and catecholamines in chromaffin granules of neuroendocrine cells in the adrenal medulla [25]. CgA is also present in other secretory vesicles of neuronal and endocrine tissues including the pancreatic islet, in addition to keratinocytes, cardiomyocytes, ECs, and macrophages $[3,19,20]$.

Human CHGA spans 12,192 base pairs and originates in eight exons and seven introns [36]. The derived transcript of 2041 base pairs is translated into the 457 residues pre-CgA protein $(51 \mathrm{kDa})$, including an 18 amino acid signal sequence $[29,37]$. The human mature $\mathrm{CgA}$ protein consists of 439 amino acids $(49 \mathrm{kDa})$ and is characterized by $8-10$ pairs of dibasic cleavage sites $[36,37]$. CgA can be proteolytically processed in various tissues and thereby serves as a precursor for several biological active peptides [36]. The cleavage of $\mathrm{CgA}$ at its dibasic sites is performed by intragranular and extracellular proteases, such as the following prohormone convertase 1 (PC1), $\mathrm{PC} 2$, furin, cysteine protease cathepsin $\mathrm{L}$, the serine proteases plasmin and thrombin, and also by kallikrein [3,37]. On the basis of the cleavage sites, post-translational modifications (glycosylation and phosphorylation), and proteolytic processing, human CgA (457 amino acids) can result in nine biological active peptides including the following: vasostatin-1 (CgA1-76), vasostatin-2 (CgA1-113), chromofungin (CgA47-66), chromostatin (CgA124-143), pancreastatin (CgA250-301), WE-14 (CgA324337), cateslytin (CgA344-358), catestatin (CgA352-372), and serpinin (CgA402-439) [36] (Figure 1). In addition, bovine $\mathrm{CgA}$ (449 amino acids) contains the two biological active peptides, VIF (CgA79-113) and chromacin (CgA173-194) [29]. However, VIF and chromacin have been recently demonstrated to be present in human blood and tissues $[23,38]$.

\section{Human CgA Precursor (457aa)}

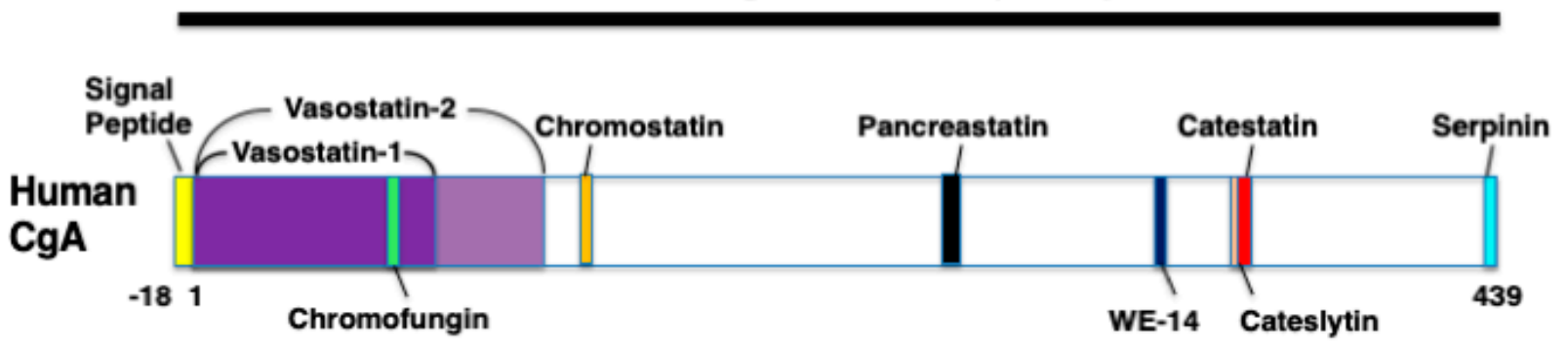

Human $\mathrm{CgC}$ Precursor (617aa)

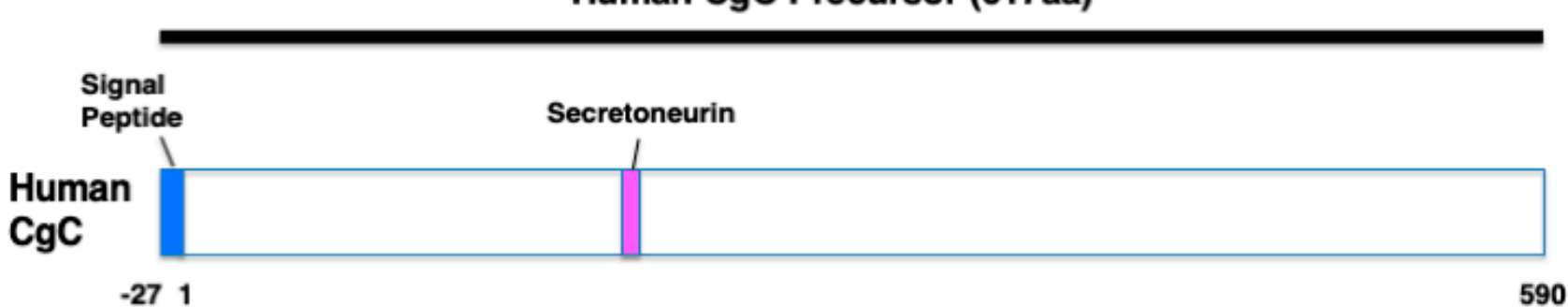

Figure 1. The domains of the various biologically active polypeptides derived from human chromogranin $\mathrm{A}(\mathrm{CgA})$ and human chromogranin C (CgC). Schematic diagrams showing vasostatin-1 (CgA1-76), vasostatin-2 (CgA1-113), chromofungin (CgA47-66), chromostatin (CgA124-143), pancreastatin (CgA250-301), WE-14 (CgA324-337), cateslytin (CgA344-358), catestatin (CgA352-372), serpinin (CgA402-439), and secretoneurin (SgII154-186).

$\mathrm{CgB}$ is abundantly expressed in many neurons and endocrine cells [3]. After synthesis, $\mathrm{CgB}$ is posttranslationally O-glycosylated and stored to large secretory vesicles [3]. Within granules, $\mathrm{CgB}$ is proteolytically processed at diabasic Lys-Arg and monobasic Arg sites to several proteins of intermediate size and small peptides [3]. From bovine CgB (646 amino 
acids), the 13-amino acid peptide secretolytin (CgB614-626) was identified, and has the biological activity as an antibacterial agent [39]. Secretolytin has been also found in human blood [40].

$\mathrm{CgC}$ is produced in the brain at the highest degree of $>90 \%$ [41]. $\mathrm{CgC}$ is also abundantly expressed in spinal cord, skeletal muscle, and myocardium [41,42]. $\mathrm{CgC}$ is cleaved by the proteases PC1/3 and PC2 to the 33-amino acid peptide secretoneurin (SgII154186) [42] (Figure 1). The activity of these proteases is increased three-fold in the failing myocardium [42]. Under pathophysiological conditions, such as hypoxia, secretoneurin expression is increased in the brain, skeletal muscle, and myocardium [41-43].

The roles of Cgs and their cleavage products as the biomarkers and pathogenesis of diabetes and atherosclerotic cardiovascular diseases are described in the following chapters.

\section{Biomarker for Diabetes, Metabolic Syndrome, and Cardiovascular Disease}

The half-life of $\mathrm{CgA}$ is relatively long; 18.4 minutes in vivo in humans [44]. Circulating CgA concentrations are 25-100 $\mathrm{ng} / \mathrm{mL}$ under normal conditions and increase under physio-pathological conditions [45]. In particular, plasma CgA concentrations increase by 12.5-fold in patients with pheochromocytoma compared with normal men [44].

$\mathrm{CgA}$ is known as an important biomarker of diabetes and cardiovascular diseases in addition to neuroendocrine tumors [38,46,47]. Higher levels of $\mathrm{CgA}$ in the circulating blood have been reported in patients with type 1 diabetes, but not those with type 2 diabetes, when compared with control subjects [47] (Table 1). Plasma levels of pancreastatin are higher in patients with type 2 and gestational diabetes compared with control subjects $[48,49]$ (Table 1). In contrast, serum levels of vasostatin-2 are lower in type 2 diabetic patients than in nondiabetic controls [50]. Serum $\mathrm{CgB}$ levels are lower in patients with type 1 diabetes, but not those with type 2 diabetes, when compared with control subjects [47] (Table 1). There are no significant correlations between serum CgA and CgB levels [47]. Serum catestatin levels are decreased in patients with metabolic syndrome compared with patients in the control category [51].

Table 1. Circulating concentrations $(\mathrm{ng} / \mathrm{mL})$ of $\mathrm{CgA}, \mathrm{CgB}$, and pancreastatin in diabetes.

\begin{tabular}{|c|c|c|c|c|c|c|c|c|}
\hline & $\begin{array}{c}\text { Type } 1 \\
\text { Diabetes }\end{array}$ & Control & $p$ Value & Ref & $\begin{array}{c}\text { Type } 2 \\
\text { Diabetes }\end{array}$ & Control & $p$ Value & Ref \\
\hline $\mathrm{CgA}$ & $61.64 \pm 55.27 \uparrow$ & $48.03 \pm 19.99$ & 0.0348 & [47] & $57.80 \pm 34.74$ & $49.97 \pm 22.29$ & 0.1587 & [47] \\
\hline $\mathrm{CgB}$ & $89.39 \pm 34.23 \downarrow$ & $107.38 \pm 59.77$ & 0.0241 & [47] & $99.72 \pm 54.79$ & $112.54 \pm 61.68$ & 0.1698 & [47] \\
\hline Pancreastatin & $\mathrm{NE}$ & $\mathrm{NE}$ & $\mathrm{NE}$ & - & $0.097 \pm 0.022 \uparrow$ & $0.026 \pm 0.004$ & 0.009 & [48] \\
\hline
\end{tabular}

Data are shown as mean \pm SD. $\mathrm{NE}=$ not examined.

Since $\mathrm{CgA}$ is even more stable compared with cathecholamines in the circulating blood, its plasma levels reflect the sympathetic tone and adrenomedullary system activity, which are altered in coronary artery disease (CAD), heart failure, and hypertension [37]. Circulating levels of $\mathrm{CgA}$ are increased and associated with the mortality of patients with CAD [52-55] (Table 2). In CAD patients, plasma CgA levels rise even higher in the presence of heart failure [55]. Plasma levels of vasostatin-1 are positively associated with carotid atherosclerosis [56]. In contrast, circulating levels of vasostatin- 2 and catestatin are significantly decreased in patients with CAD compared with healthy control groups of patients $[19,50,57,58]$ (Table 2). Serum levels of vasostatin-2 are also decreased in patients with ischemic chronic heart failure [59]. However, catestatin levels are increased at the onset of acute myocardial infarction, which is correlated with norepinephrine levels [60], and leads to adverse events [61]. In addition, the increase in catestatin levels also contributes to coronary collateral development and left ventricular remodeling [62-64]. Plasma levels of vasostatin- 1 and secretolytin are increased in patients with coronary artery bypass graft surgery [40]. 
Table 2. Circulating concentrations (ng/mL) of CgA, catestatin, vasostatin-2 in coronary heart disease (CHD) and hypertension.

\begin{tabular}{|c|c|c|c|c|c|c|c|c|}
\hline & CAD & Control & $p$ Value & Ref & Hypertension & Control & $p$ Value & Ref \\
\hline $\mathrm{CgA}$ & $358 \pm 304 \uparrow$ & $108 \pm 74$ & 0.017 & [52] & $99.9 \pm 6.7 \uparrow$ & $62.8 \pm 4.7$ & $<0.001$ & [65] \\
\hline Catestatin & $2.09 \pm 1.42 \downarrow$ & $4.05 \pm 3.52$ & 0.0112 & [19] & $2.27 \pm 0.83 \uparrow$ & $1.92 \pm 0.49$ & 0.004 & [66] \\
\hline Vasostatin-2 & $4.45 \pm 2.64 \downarrow$ & $5.82 \pm 3.22$ & $<0.001$ & [50] & $\mathrm{NE}$ & $\mathrm{NE}$ & $\mathrm{NE}$ & - \\
\hline
\end{tabular}

Data are shown as mean $\pm \mathrm{SD}$. CAD = coronary artery disease, $\mathrm{NE}=$ not examined.

Plasma levels of $\mathrm{CgA}$, catestatin, and pancreastatin are significantly increased in patients with hypertension compared with healthy control subjects [65-67] (Table 2). There are higher plasma levels of $\mathrm{CgA}, \mathrm{CgB}$, catestatin, VIF, and secretoneurin in patients with heart failure compared with healthy control groups of patients [23,42,68-70]. Serum levels of $\mathrm{CgA}$ and $\mathrm{CgB}$ are significantly higher in the presence of carcinoid heart disease among patients with neuroendocrine tumors [71]. Levels of plasma CgA are much higher in patients with dilated cardiomyopathy or hypertrophic cardiomyopathy than the levels in the healthy controls [72]. Plasma vasostatin-1 levels are increased in patients with Takayasu arteritis [73]. High levels of secretoneurin are associated with the increased risk of mortality in patients with heart failure, aortic stenosis, or those patients undergoing various cardiac surgeries [74-76].

$\mathrm{CgA}$ is detected at higher levels in the saliva of type 2 diabetic patients compared with healthy and nondiabetic subjects [77,78]. In patients with type 2 diabetes, the high levels of salivary $\mathrm{CgA}$ are associated with periodontal damage [78]. Therefore, $\mathrm{CgA}$ in saliva may be a biomarker for oral health in patients with type 2 diabetes. The levels of $\mathrm{CgA}, \mathrm{CgB}$, and $\mathrm{CgC}$ in the vitreous humor are higher in patients with diabetic retinopathy compared with nondiabetic subjects [79].

As clinical biomarkers, $\mathrm{CgA}, \mathrm{CgB}, \mathrm{CgC}$, and derived polypeptides are closely associated with atherosclerotic cardiovascular diseases and diabetes. Next, this review describes their cardiovascular effects as well as the molecular and cellular mechanisms of their antiatherosclerotic and anti-diabetic effects, and expands to their emerging roles in therapeutic strategies against atherosclerotic cardiovascular diseases and diabetes.

\section{Cardiovascular Effects}

Catestatin reduces blood pressure by inhibiting catecholamine secretion and stimulating histamine release [80]. Catestatin infusion directly dilates human blood vessels [81]. Catestatin and vasostatin-1 exert vasodilatory effects via nitric oxide (NO) release from vascular endothelial cells (ECs) [22]. Vasostatins and chromostatin suppress endothelin1 -induced vasoconstriction in human blood vessels $[82,83]$. VIF suppresses the vasoconstrictive effect of angiotensin II via AT2 receptor [23]. Pancreastatin activates Galpha16 and phospholipase $C-\beta 2$ in myocardial membrane, suggesting that pancreastatin may regulate cardiac function [84]. Although chromofungin and chromacin have antimicrobial effects $[85,86]$, their cardiovascular effects have not yet been elucidated. Serpinin enhances cardiac contractility (inotropy) via $\beta$-adrenergic receptors [87]. Cateslytin protects cardiomyocytes against lipopolysaccharide (LPS)-induced injury by decreasing inflammation and oxidized stress via toll-like receptor-4 [88]. Catestatin and the $\mathrm{CgC}$-derived peptide secretoneurin stimulate ischemia-induced angiogenesis [89,90], but vasostatin-1 inhibits tumor angiogenesis and ocular neovascularization [91,92]. Secretoneurin protects against ischemic injury and apoptosis in the brain and skeletal muscle [42], and also improves cardiac dysfunction and inhibits cardiac remodeling following myocardial infarction [93].

In addition to cardiovascular protective effects, the atheroprotective effects of Cgsderived polypeptides in vitro and in vivo are especially described in the next Chapter.

\section{Atherosclerosis}

Atherosclerosis is triggered by arterial injury-induced inflammation. This process includes hyperpermeability, proliferation of ECs followed by the formation of atheroma- 
tous plaques involving oxidized LDL-induced foam cell formation in monocyte-derived macrophages, migration and proliferation of VSMCs, and extracellular matrix production by VSMCs [2] (Figure 2). As described above, in the formation and development of atherosclerosis in the arterial walls, three types of vascular cells, such as ECs, macrophage, and VSMCs, are known as the major players. Therefore, the effects of CgA- and CgCderived polypeptides on these vascular cells are described in detail in the following sections.

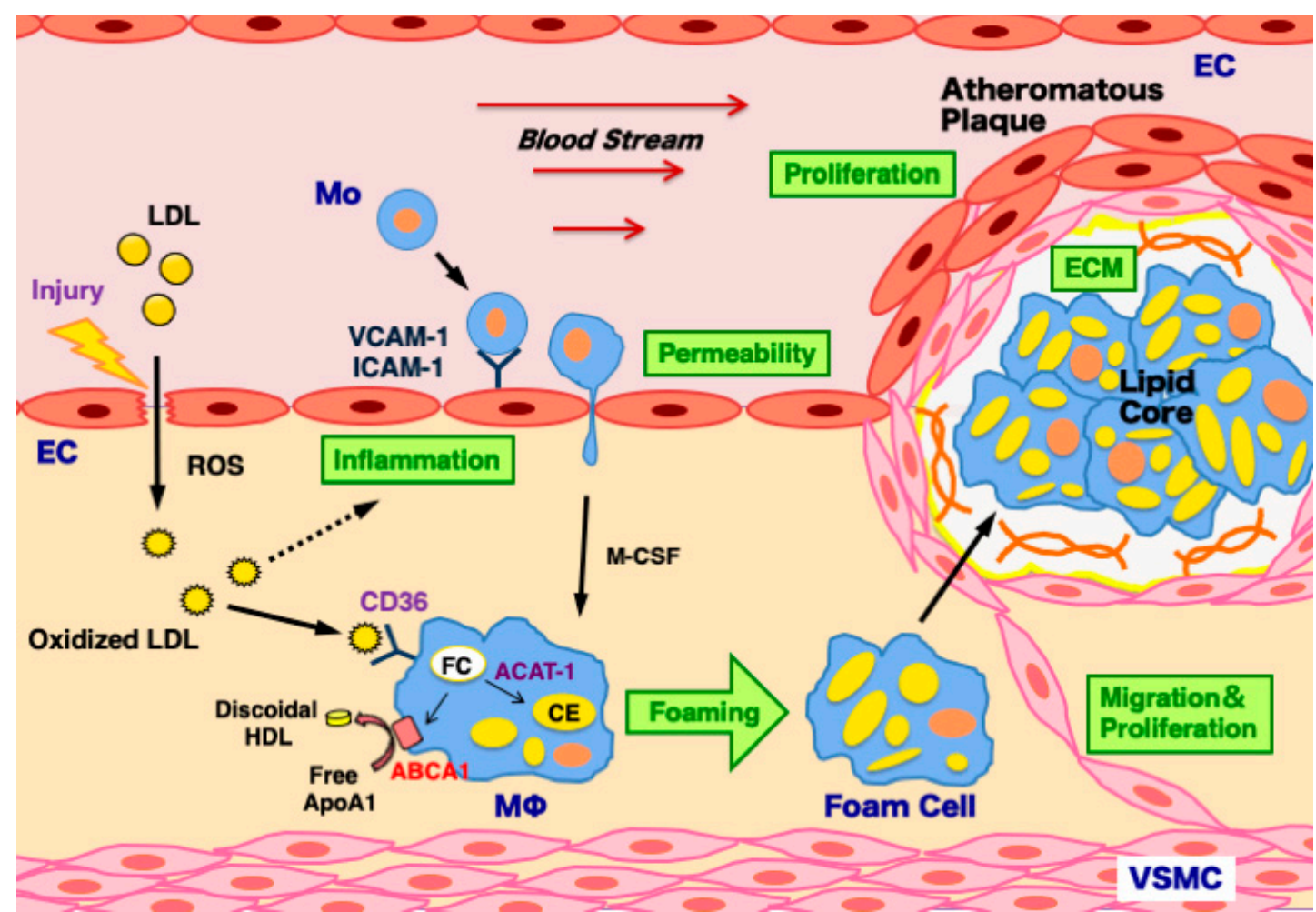

Figure 2. Mechanisms of atherosclerosis development in the arterial wall. Atherosclerosis is triggered by arterial injury-induced inflammation and hyperpermeability in endothelial cells (ECs). This process induces the infiltration of low-density lipoprotein (LDL) particles into the subendothelial space, and LDL is modified to oxidized LDL by reactive oxygen species (ROS), which further accelerates vascular inflammation. It stimulates monocyte adhesion to ECs via vascular cell adhesion molecule-1 (VCAM-1) and intercellular adhesion molecule-1 (ICAM-1) upregulation. Monocytes (Mo) infiltrate into the subendothelial space and then differentiate to macrophages $(\mathrm{M} \phi)$ by macrophage colony stimulating factor (M-CSF). Macrophages uptake oxidized LDL via its receptor CD36 upregulation, and transform to foam cells via the decreased efflux of free cholesterol (FC) by the ATP-binding cassette transporter A1 (ABCA1) downregulation and increased cholesterol ester (CE) biosynthesis by acyl coenzyme A: cholesterol acyltransferase-1 (ACAT-1) upregulation. The massive accumulation of foam cells results in the formation of lipid core. To surround it, vascular smooth muscle cells (VSMCs) migrate, proliferate, and produce extracellular matrix (ECM), leading to the development of atheromatous plaques.

\subsection{ECS}

Early atherosclerosis features vascular injury-induced changes in endothelial structure and barrier function that affect the traffic of molecules and solutes between the vessel lumen and the vascular wall [2]. Proatherogenic stimuli and cardiovascular risk factors, such as hypertension, dyslipidemia, diabetes, and smoking, increase endothelial permeability [94]. These factors share a common signaling denominator: an imbalance in the production/disposal of reactive oxygen species (ROS), broadly termed oxidative stress [94]. As a consequence of the activation of enzymatic systems leading to ROS overproduction, proatherogenic factors lead to a proinflammatory status that translates to changes in gene expression and functional rearrangements, including changes in the transendothelial transport of LDL [94]. Oxidation of LDL by ROS triggers the expression of adhesion molecules, such as vascular cell adhesion molecule-1 (VCAM-1) and intercellular adhesion 
molecule-1 (ICAM-1) in ECs [2]. Circulating monocytes attach to ECs and subsequently infiltrate into the intima [2]. In addition, EC proliferation contributes to the formation of intimal lesions [95]. The migration and proliferation of ECs are important phenomena for angiogenesis and also atherogenesis.

$\mathrm{CgA}$, catestatin, vasostatin-1, and chromofungin suppress the permeability in ECs [91,96-98] (Table 3). Vasostatin-1 inhibits tumor necrosis factor- $\alpha$ (TNF- $\alpha$ )-induced gap formation in ECs [99], and also suppresses vascular endothelial growth factor (VEGF)induced migration and proliferation of ECs [100] (Table 3). In contrast, secretoneurin activates transendothelial extravasation [101]. Catestatin and secretoneurin stimulate the migration and proliferation of ECs $[89,102]$ (Table 3), contributing to angiogenesis. However, secretoneurin suppresses VEGF-induced EC proliferation [103] (Table 3).

Table 3. Effects of CgA, catestatin, vasostatin-1, vasostatin-2, and secretoneurin on vascular cell responses for atherosclerosis.

\begin{tabular}{|c|c|c|c|c|c|c|c|c|}
\hline & \multicolumn{3}{|c|}{ EC } & \multirow{2}{*}{$\begin{array}{c}\text { Macrophage } \\
\text { Foaming Cell }\end{array}$} & \multicolumn{4}{|c|}{ VSMC } \\
\hline & Permeability & Proliferation & VCAM-1 & & Migration & Proliferation & Collagen & Elastin \\
\hline $\mathrm{CgA}$ & $\downarrow$ & NE & $\mathrm{NE}$ & $\mathrm{NE}$ & $\mathrm{NE}$ & $\mathrm{NE}$ & $\mathrm{NE}$ & $\mathrm{NE}$ \\
\hline Catestatin & $\downarrow$ & $\uparrow$ & $\downarrow$ & $\downarrow$ & $\downarrow$ & $\downarrow$ & $\downarrow\left({ }^{*} 1\right)$ & $\uparrow$ \\
\hline Vasostatin-1 & $\downarrow$ & $\downarrow$ & $\downarrow$ & $\downarrow$ & $\downarrow$ & $\rightarrow$ & $\downarrow(* 2)$ & $\uparrow$ \\
\hline Vasostatin-2 & $\mathrm{NE}$ & $\uparrow$ & $\downarrow$ & $\mathrm{NE}$ & $\downarrow$ & $\downarrow$ & $\mathrm{NE}$ & $\mathrm{NE}$ \\
\hline Secretoneurin & $\uparrow$ & $\uparrow$ or $\downarrow$ & $\uparrow$ & $\mathrm{NE}$ & NE & $\uparrow$ & $\mathrm{NE}$ & $\mathrm{NE}$ \\
\hline
\end{tabular}

EC, endothelial cell; VSMC, vascular smooth muscle cell; NE, not examined. Arrows show these polypeptides-induced changes in each phenomenon. Catestatin and vasostatin-1 suppress the expression of collagen-1 $\left({ }^{*} 1\right)$ and collagen-3 $(* 2)$, respectively.

Catestatin, vasostain-1, and vasostatin-2 suppress LPS- or TNF- $\alpha$-induced expression of VCAM-1 and ICAM-1 in human ECs $[19,20,50]$ (Table 3). Vasostatin-1 and vasostatin2 , but not catestatin, suppress LPS- or TNF- $\alpha$-induced E-selectin expression, respectively $[19,20,50]$. Catestatin suppresses LPS-induced TNF- $\alpha$ expression [19], and vasostatin1 suppresses LPS-induced expression of monocyte chemoattractant protein-1 (MCP-1) in human ECs [20]. Catestatin suppresses the adhesion of leukocytes to ECs [57]. Both vasostatin-1 and vasostatin-2 also suppress the adhesion of human monocytes to human ECs $[20,50]$. In contrast, secretoneurin stimulates the adhesion of human monocytes to human ECs [104]. Secretoneurin also upregulates basic fibroblast growth factor, plateletderived growth factor-B, and VEGF, and activates NO synthase in ECs $[93,102]$. Secretoneurin induces endothelium-dependent relaxations in porcine coronary arteries [105].

\subsection{Macrophages}

Monocytes migrate into the subendothelial space, and then differentiate to macrophages [2]. Macrophages phagocytose oxidized LDL and transform into foam cells [2]. Foam cell formation depends on the homeostatic balance between the uptake of oxidized LDL via CD36, the efflux of free cholesterol controlled by the ATP-binding cassette transporter A1 (ABCA1), and cholesterol esterification by acyl coenzyme A: cholesterol acyltransferase-1 (ACAT-1) [106].

Catestatin and secretoneurin stimulate the migration of human monocytes $[107,108]$. These findings suggest that the two peptides contribute to the biodefence and inflammatory response in vascular walls. Catestatin and vasostatin- 1 induce the anti-inflammatory phenotype and suppress the inflammation in human macrophages $[19,20,109]$.

Catestatin and vasostatin-1 suppress oxidized LDL-induced foam cell formation in human macrophages $[19,20]$ (Table 3). Macrophage foam cell formation by vasostatin-2 and pancreastatin has not yet been evaluated. Catestatin decreases ACAT-1 expression but increases ABCA1 expression without affecting CD36 expression in human macrophages [19]. Vasostatin-1 decreases both CD36 and ACAT-1 expression but increases ABCA1 expression in human macrophages [20]. Pancreastatin does not affect the expression of CD36, ACAT-1, and $\mathrm{ABCA} 1$ in human macrophages (Figure S1). 


\section{3. $V S M C s$}

VSMCs contribute to the progression of atherosclerotic plaque through their migration, proliferation, and the production of ECM components, such as collagens, matrix metalloproteinases, fibronectin, and elastin. In particular, collagens promote the formation of the fibrous cap of atherosclerotic plaques [110]. The fibrous cap contributes to stabilizing atherosclerotic plaque to prevent its rupture. Elastin plays an essential role in the maintenance of vascular elasticity [111].

Catestatin, vasostatin-1, and vasostatin-2 suppress the migration of human VSMCs $[19,20,112]$ (Table 3). Catestatin and vasostatin-2, but not vasostatin-1, suppress the proliferation of human VSMCs $[19,20,112]$ (Table 3). In contrast, catestatin and secretoneurin promote the proliferation of VSMCs in rats $[113,114]$ (Table 3).

In VSMCs, catestatin and vasostatin-1 suppress the expression of collagen- 1 and collagen-3, respectively, and both peptides increase elastin expression [19,20] (Table 3). These findings suggest that catestatin and vasostatin- 1 contribute to suppressing plaque progression and preserving vascular elasticity. Secretoneurin stimulates the expression of MCP-1 and VCAM-1 in VSMCs [115].

\subsection{Murine Models of Atherosclerosis}

The in vivo effects of $\mathrm{CgA}$ and its derived peptides on atherosclerosis have been evaluated in murine models with their exogenous infusion and endogenous deficiency. A chronic infusion of catestatin, vasostatin-1, or vasostatin-2 suppresses the development of atherosclerosis of the aorta in apolipoprotein E-deficient mice [19-21]. These anti-atherosclerotic effects are attributed to the molecular and cellular protective effects against atherosclerosis, as described above. Catestatin also attenuates insulin resistance, hypertension, and obesity in murine models, and contributes to the prevention of metabolic syndrome [116]. CgA-knockout mice reveal hypertension, high plasma catecholamine and adiponectin levels, and lower interleukin-6 and lipid levels compared with wild type mice [117]. CgA-knockout mice also exhibit enhanced insulin sensitivity despite obesity [118]. These findings suggest that $\mathrm{CgA}$ prevents the development of atherosclerosis. Next, the preventive effects of $\mathrm{CgA}$ and derived peptides on atherosclerotic cardiovascular diseases in murine models are described.

\section{Myocardial Ischemia/Reperfusion Injury, Hind Limb Ischemia, and Stroke}

$\mathrm{CgA}$ dilates coronary arteries and induces negative inotropic effects via Akt/NO/cGMP/ protein kinase $G$ pathway in hypertensive rat hearts [119]. Catestatin, vasostatin-1, and chromofungin protect ischemia/reperfusion-induced myocardial dysfunction via the NOdependent pathway in rats [120-122]. Vasostatin-2 protects against ischemic heart failure in rats with myocardial infarction [59]. A CgA-derived peptide named pGlu-serpinin protects ischemia/reperfusion-induced myocardial dysfunction in normotensive and hypertensive rats [123]. Pretreated H9c2 cells (embryonic rat cardiomyocytes) with pGlu-serpinin are protected against hypoxia/reoxygenation [123]. Serpinin enhances myocardial contractility via $\beta$-adrenergic receptors followed by the adenylate cyclase/cAMP/protein kinase A pathway [87].

In addition, gene therapy with the $\mathrm{CgC}$-derived peptide secretoneurin ameliorates hind limb and myocardial ischemia without influencing systemic atherosclerosis in apolipoprotein E-deficient mice [124]. Secretoneurin protects skeletal muscle and myocardium against ischemic injury and apoptosis [42]. Secretoneurin gene therapy has a variety of effects. It stimulates coronary angiogenesis, improves left ventricular function, and inhibits myocardial remodeling in a rat model of myocardial infraction [93]. Oral administration of secretoneurin enveloped in nanoparticles restores blood flow in the mouse hind limb ischemia model [125]. Secretoneurin gene therapy also stimulates postischemic neovascularization in streptozotocin-induced diabetic mice [126], and improves diabetic neuropathy in $\mathrm{db} / \mathrm{db}$ mice [127]. Secretoneurin suppresses hypertrophy and oxidative stress via AMPactivated protein kinase (AMPK)/extracellular signal-regulated kinase (ERK) pathways in 
mouse cardiomyocytes [128]. Secretoneurin promotes neuroprotection and neuroplasticity via the Janus kinase-2/signal transducer and activator of transcription-3 pathway in murine models of stroke $[129,130]$.

\section{Diabetes}

$\mathrm{CgA}$ is known to play a significant role in the pathogenesis and development of type 1 diabetes [10]. In vivo and in vitro experiments have determined that the function of $\mathrm{CgB}$ relates to the physiological secretion of insulin. $\mathrm{CgB}$ regulates early-stage insulin granule trafficking from the Golgi in pancreatic islet $\beta$-cells [34]. Catestatin suppresses hepatic glucose production and improves insulin sensitivity [131]. WE-14 (the abbreviation comes from N- and C-terminal amino acids and the length of the molecule) and human CgA10-19 serve as an autoantigen for both CD4+ and CD8+ $\beta$-cell-destructive diabetogenic T-cell clones in type 1 diabetes [132,133]. A recent study has identified a CgA29-42 peptide within vasostatin-1, an N-terminal natural derivative of CgA, as the BDC2.5 TCR epitope [134]. Having the necessary motif for binding to I-A(g7), it activates BDC2.5 T-cells and induces an interferon- $\gamma$ response [134]. More importantly, adoptive transfer of naive BDC2.5 splenocytes activated with CgA29-42 peptide transferred diabetes into NOD/SCID mice [134].

Pancreastatin inhibits insulin secretion from pancreatic islet $\beta$-cells [12] and also regulates glucose, lipid, and protein metabolism in liver and adipose tissues [135]. Pancreastatin inhibits glucose uptake and glycogen synthesis but stimulates gluconeogenesis in hepatocytes [135]. Pancreastatin inhibits glucose uptake and glycogen synthesis in adipocytes [136]. Pancreastatin increases lipid droplets and ROS production in 3T3-L1 adipocyte cells [137]. These effects of pancreastatin are exerted via phosphatidylinositol 3-kinase/protein kinase C and glycogen synthase kinase-3 [136]. Pancreastatin plays a significant role in obesity-induced insulin resistance [138]. In healthy humans, a standard meal increases serum pancreastatin levels [139], and human pancreastatin infusion decreases forearm glucose uptake [140]. An intravenous infusion of human pancreastatin-16 suppresses the elevation of serum insulin levels without glucose overshoot on an oral glucose tolerance test in healthy humans [141]. Pancreastatin may induce the impaired insulin secretion and insulin resistance in the setting of diabetes and/or obesity.

Pancreastatin inhibitor peptide-8 (PSTi8), which consists of 21 amino acids (PEGKGEQEHSQQKEEEEEMAV-amide), exerts antidiabetic effects. These effects have been demonstrated by cell and animal studies [13,142-144]. PSTi8 decreases pancreastatininduced insulin resistance in HepG2 cells (human liver cancer cells) and 3T3-L1 cells (mouse adipocyte cells) [13,142]. PSTi8 increases glucose uptake via enhanced glucose transporter type 4 in L6 cells (rat skeletal myoblast cells) $[13,143]$ and decreases hepatic glucose release [144]. The treatment with PSTi8 increases insulin sensitivity in $\mathrm{db} / \mathrm{db}$, high fat and fructose-fed streptozotocin-induced insulin resistance mice [13]. PSTi8 improves the obesity-associated insulin resistance and inflammation in skeletal muscle [143], and improves hyperinsulinemia-induced obesity and inflammation-mediated insulin resistance in adipose tissue via inhibition of ERK/c-Jun N-terminal protein kinase pathways [137]. PSTi8 also improves dexamethasone-induced fatty liver by suppressing lipid deposition and oxidative stress through the glucose-regulated protein-78 followed by the AMPK pathway [144]. Further clinical studies are needed to clarify the efficacy of PSTi8 in the treatment of patients with diabetes and obesity.

\section{Conclusions}

$\mathrm{CgA}$ and derived polypeptides are the convincing biomarkers for atherosclerosis, diabetes, hypertension, and cardiovascular diseases. Circulating levels of CgA and pancreastain are high in type 1 and type 2 diabetes, respectively, because $\mathrm{CgA}$ is one of pathogeneses of type 1 diabetes, and pancreastatin induces insulin hyposecretion and insulin resistance. Circulating CgA levels are high in hypertension, CAD, and heart failure that show increments in the sympathetic tone and adrenomedullary system activity. Circu- 
lating levels of catestatin and vasostatin-2 are low in CAD. As catestatin and vasostatin-2 have atheroprotective effects, their decreased levels may be a risk factor for CAD.

PSTi8 is useful in the treatment of diabetes and metabolic syndrome. Catestatin, vasostatin-1, and vasostatin-2 serve the therapeutic target for atherosclerosis and coronary heart disease. Vasostatin-1 and secretoneurin stimulate ischemia-induced angiogenesis. Catestatin, vasostatin-1, and chromofungin protect ischemic myocardial damage. Cgs and derived polypeptides are a vision of new therapeutic strategies for atherosclerotic and ischemic cardiovascular diseases.

Supplementary Materials: The following are available online at https:/ /www.mdpi.com/article/10 $.3390 / \mathrm{ijms} 22116118 / \mathrm{s} 1$.

Funding: This research received no external funding.

Institutional Review Board Statement: Not applicable.

Informed Consent Statement: Not applicable.

Data Availability Statement: Not applicable.

Acknowledgments: The author thanks Sato K, Watanabe R, Kojima M, Ozawa N, Sato Y, and Niimura $\mathrm{T}$ for data acquisition and Terasaki $\mathrm{T}$ for reference collection.

Conflicts of Interest: The author declares no conflict of interest.

$\begin{array}{ll}\text { Abbreviations } \\ \text { ABCA1 } & \text { ATP-binding cassette transporter A1 } \\ \text { ACAT-1 } & \text { Acyl coenzyme A: cholesterol acyltransferase-1 } \\ \text { AMPK } & \text { AMP-activated protein kinase } \\ \text { Cg } & \text { Chromogranin } \\ \text { CAD } & \text { Coronary artery disease } \\ \text { CE } & \text { Cholesterol ester } \\ \text { EC } & \text { Endothelial cell } \\ \text { ECM } & \text { Extracellular matrix } \\ \text { FC } & \text { Free cholesterol } \\ \text { ICAM-1 } & \text { Intercellular adhesion molecule-1 } \\ \text { LDL } & \text { Low-density lipoprotein } \\ \text { LPS } & \text { lipopolysaccharide } \\ \text { MCP-1 } & \text { Monocyte chemoattractant protein-1 } \\ \text { M-CSF } & \text { Macrophage colony stimulating factor } \\ \text { NO } & \text { Nitric oxide } \\ \text { PC } & \text { Prohormone convertase } \\ \text { PSTi8 } & \text { Pancreastatin inhibitor peptide-8 } \\ \text { ROS } & \text { Reactive oxygen species } \\ \text { TNF- } \alpha & \text { Tumor necrosis factor- } \alpha \\ \text { VCAM-1 } & \text { Vascular cell adhesion molecule-1 } \\ \text { VEGF } & \text { Vascular endothelial growth factor } \\ \text { VIF } & \text { Vasoconstriction-inhibiting factor } \\ \text { VSMC } & \text { Vascular smooth muscle cell } \\ & \end{array}$

\section{References}

1. Malakar, A.K.; Choudhury, D.; Halder, B.; Paul, P.; Uddin, A.; Chakraborty, S. A review on coronary artery disease, its risk factors, and therapeutics. J. Cell. Physiol. 2019, 234, 16812-16823. [CrossRef] [PubMed]

2. Wolf, M.P.; Hunziker, P. Atherosclerosis: Insights into vascular pathobiology and outlook to novel treatments. J. Cardiovasc. Transl. Res. 2020, 13, 744-757. [CrossRef]

3. Bartolomucci, A.; Possenti, R.; Mahata, S.K.; Fischer-Colbrie, R.; Loh, Y.P.; Salton, S.R.J. The extended granin family: Structure, function, and biomedical implications. Endocr. Rev. 2011, 32, 755-797. [CrossRef] 
4. Cohn, D.V.; Zangerle, R.; Fischer-Colbrie, R.; Chu, L.L.; Elting, J.J.; Hamilton, J.W.; Winkler, H. Similarity of secretory protein I from parathyroid gland to chromogranin A from adrenal medulla. Proc. Natl. Acad. Sci. USA 1982, 79, 6056-6059. [CrossRef] [PubMed]

5. Huh, Y.H.; Jeon, S.H.; Yoo, S.H. Chromogranin B-induced secretory granule biogenesis: Comparison with the similar role of chromogranin A. J. Biol. Chem. 2003, 278, 40581-40589. [CrossRef] [PubMed]

6. Fischer-Colbrie, R.; Hagn, C.; Kilpatrick, L.; Winkler, H. Chromogranin C: A third component of the acidic proteins in chromaffin granules. J. Neurochem. 1986, 47, 318-321. [CrossRef]

7. Goetze, J.P.; Hilsted, L.M.; Rehfeld, J.F. Chromogranin A in cardiovascular endocrinology. Acta Physiol. 2021, 231 , e13615. [CrossRef]

8. Ebert, A.; König, J.; Frommer, L.; Schuppan, D.; Kahaly, G.J. Chromogranins serves as novel biomarker of endocrine and gastric autoimmunity. J. Clin. Endocrinol. Metab. 2020, 105, dgaa288. [CrossRef] [PubMed]

9. Herold, Z.; Herold, M.; Nagy, P.; Patocs, A.; Doleschall, M.; Somogyi, A. Serum chromogranin A level continuously rises with the progression of type 1diabetes, and indicates the presence of both enterochromaffin-like cell hyperplasia and autoimmune gastritis. J. Diabetes Investig. 2020, 11, 865-873. [CrossRef]

10. Herold, Z.; Doleschall, M.; Kovesdi, A.; Patocs, A.; Somogyi, A. Chromogranin A and its role in the pathogenesis of diabetes mellitus. Endokrynol. Pol. 2018, 69, 598-610. [CrossRef] [PubMed]

11. Cetin, Y.; Aunis, D.; Bader, M.F.; Galindo, E.; Jörns, A.; Bargsten, G.; Grube, D. Chromostatin, a chromogranin A-derived bioactive peptide, is present in human pancreatic insulin ( $\beta$ ) cells. Proc. Natl. Acad. Sci. USA 1993, 90, 2360-2364. [CrossRef]

12. Tatemoto, K.; Efendić, S.; Mutt, V.; Makk, G.; Feistner, G.J.; Barchas, J.D. Pancreastatin, a novel pancreatic peptide that inhibits insulin secretion. Nature 1986, 324, 476-478. [CrossRef] [PubMed]

13. Hossain, Z.; Valicherla, G.R.; Gupta, A.P.; Syed, A.A.; Riyazuddin, M.; Chandra, S.; Siddiqi, M.I.; Gayen, J.R. Discovery of pancreastatin inhibitor PSTi8 for the treatment of insulin resistance and diabetes: Studies in rodent models of diabetes mellitus. Sci. Rep. 2018, 8, 8715. [CrossRef]

14. Zhang, K.; Chen, Y.; Wen, G.; Mahata, M.; Rao, F.; Fung, M.M.; Vaingankar, S.; Biswas, N.; Gayen, J.R.; Friese, R.S.; et al. Catecholamine storage vesicles: Role of core protein genetic polymorphisms in hypertension. Curr. Hypertens. Rep. 2011, 13, 36-45. [CrossRef] [PubMed]

15. Fung, M.M.; Nguyen, C.; Mehtani, P.; Salem, R.M.; Perez, B.; Thomas, B.; Das, M.; Schork, N.J.; Mahata, S.K.; Ziegler, M.G.; et al. Genetic variation within adrenergic pathways determines in vivo effects of presynaptic stimulation in humans. Circulation 2008, 117, 517-525. [CrossRef] [PubMed]

16. Wen, G.; Wessel, J.; Zhou, W.; Ehret, G.B.; Rao, F.; Stridsberg, M.; Mahata, S.K.; Gent, P.M.; Das, M.; Cooper, R.S.; et al. An ancestral variant of Secretogranin II confers regulation by PHOX2 transcription factors and association with hypertension. Hum. Mol. Genet. 2007, 16, 1752-1764. [CrossRef]

17. Choi, Y.; Miura, M.; Nakata, Y.; Sugasawa, T.; Nissato, S.; Otsuki, T.; Sugawara, J.; Iemitsu, M.; Kawakami, Y.; Shimano, H.; et al. A common genetic variant of the chromogranin A-derived peptide catestatin is associated with atherogenesis and hypertension in a Japanese population. Endocr. J. 2015, 62, 797-804. [CrossRef] [PubMed]

18. Kiranmayi, M.; Chirasani, V.R.; Allu, P.K.; Subramanian, L.; Martelli, E.E.; Sahu, B.S.; Vishnuprabu, D.; Kumaragurubaran, R.; Sharma, S.; Bodhini, D.; et al. Catestatin Gly364Ser variant alters systemic blood pressure and the risk for hypertension in human populations via endothelial nitric oxide pathway. Hypertension 2016, 68, 334-347. [CrossRef] [PubMed]

19. Kojima, M.; Ozawa, N.; Mori, Y.; Takahashi, Y.; Watanabe-Kominato, K.; Shirai, R.; Watanabe, R.; Sato, K.; Matsuyama, T.; Ishibashi-Ueda, H.; et al. Catestatin prevents macrophage-driven atherosclerosis but not arterial injury-induced neointimal hyperplasia. Thromb. Haemost. 2018, 118, 182-194. [CrossRef]

20. Sato, Y.; Watanabe, R.; Uchiyama, N.; Ozawa, N.; Takahashi, Y.; Shirai, R.; Sato, K.; Mori, Y.; Matsuyama, T.; Ishibashi-Ueda, H.; et al. Inhibitory effects of vasostatin-1 against atherogenesis. Clin. Sci. 2018, 132, 2493-2507. [CrossRef]

21. Xiong, W.; Wang, X.; Dai, D.; Zhang, B.; Lu, L.; Tao, R. The anti-inflammatory vasostatin-2 attenuates atherosclerosis in ApoE ${ }^{-/-}$ mice and inhibits monocyte/macrophage recruitment. Thromb. Haemost. 2017, 117, 401-414. [CrossRef] [PubMed]

22. Fornero, S.; Bassino, E.; Gallo, M.P.; Ramella, R.; Levi, R.; Alloatti, G. Endothelium dependent cardiovascular effects of the chromogranin A-derived peptides vasostatin-1 and catestatin. Curr. Med. Chem. 2012, 19, 4059-4067. [CrossRef]

23. Salem, S.; Jankowski, V.; Asare, Y.; Liehn, E.; Welker, P.; Raya-Bermudez, A.; Pineda-Martos, C.; Rodriguez, M.; Muñoz-Castañeda, J.R.; Bruck, H.; et al. Identification of the vasoconstriction-inhibiting factor (VIF), a potent endogenous cofactor of angiotensin II acting on the angiotensin II type 2 receptor. Circulation 2015, 131, 1426-1434. [CrossRef] [PubMed]

24. Troger, J.; Theurl, M.; Kirchmair, R.; Pasqua, T.; Tota, B.; Angelone, T.; Cerra, M.C.; Nowosielski, Y.; Mätzler, R.; Troger, J.; et al. Granin-derived peptides. Prog. Neurobiol. 2017, 154, 37-61. [CrossRef]

25. Blaschko, H.; Comline, R.S.; Schneider, F.H.; Silver, M.; Smith, A.D. Secretion of a chromaffin granule protein, chromogranin, from the adrenal gland after splanchnic stimulation. Nature 1967, 215, 58-59. [CrossRef]

26. Lee, R.W.; Huttner, W.B. Tyrosine-O-sulfated proteins of PC12 pheochromocytoma cells and their sulfation by a tyrosylprotein sulfotransferase. J. Biol. Chem. 1983, 258, 11326-11334. [CrossRef]

27. Gerdes, H.H.; Rosa, P.; Phillips, E.; Baeuerle, P.A.; Frank, R.; Argos, P.; Huttner, W.B. The primary structure of human secretogranin II, a widespread tyrosine-sulfated secretory granule protein that exhibits low $\mathrm{pH}$ - and calcium-induced aggregation. J. Biol. Chem. 1989, 264, 12009-12015. [CrossRef] 
28. Mahata, S.K.; Kozak, C.A.; Szpirer, J.; Szpirer, C.; Modi, W.S.; Gerdes, H.H.; Huttner, W.B.; O'Connor, D.T. Dispersion of chromogranin/secretogranin secretory protein family loci in mammalian genomes. Genomics 1996, 33, 135-139. [CrossRef]

29. Mouland, A.J.; Bevan, S.; White, J.H.; Hendy, G.N. Human chromogranin A gene. Molecular cloning, structural analysis, and neuroendocrine cell-specific expression. J. Biol. Chem. 1994, 269, 6918-6926. [CrossRef]

30. Greenwood, T.A.; Cadman, P.E.; Stridsberg, M.; Nguyen, S.; Taupenot, L.; Schork, N.J.; O'Connor, D.T. Genome-wide linkage analysis of chromogranin $\mathrm{B}$ expression in the $\mathrm{CEPH}$ pedigrees: Implications for exocytotic sympathochromaffin secretion in humans. Physiol. Genomics 2004, 18, 119-127. [CrossRef] [PubMed]

31. Benedum, U.M.; Lamouroux, A.; Konecki, D.S.; Rosa, P.; Hille, A.; Baeuerle, P.A.; Frank, R.; Lottspeich, F.; Mallet, J.; Huttner, W.B. The primary structure of human secretogranin I (chromogranin B): Comparison with chromogranin A reveals homologous terminal domains and a large intervening variable region. EMBO J. 1987, 6, 1203-1211. [CrossRef] [PubMed]

32. Scammell, J.G.; Reddy, S.; Valentine, D.L.; Coker, T.N.; Nikolopoulos, S.N.; Ross, R.A. Isolation and characterization of the human secretogranin II gene promoter. Brain Res. Mol. Brain Res. 2000, 75, 8-15. [CrossRef]

33. Fargali, S.; Garcia, A.L.; Sadahiro, M.; Jiang, C.; Janssen, W.G.; Lin, W.J.; Cogliani, V.; Elste, A.; Mortillo, S.; Cero, C.; et al. The granin VGF promotes genesis of secretory vesicles, and regulatescirculating catecholamine levels and blood pressure. FASEB J. 2014, 28, 2120-2133. [CrossRef]

34. Bearrows, S.C.; Bauchle, C.J.; Becker, M.; Haldeman, J.M.; Swaminathan, S.; Stephens, S.B. Chromogranin B regulates early-stage insulin granule trafficking from the Golgi in pancreatic islet $\beta$-cells. J. Cell Sci. 2019, 132, jcs231373. [CrossRef]

35. Saria, A.; Troger, J.; Kirchmair, R.; Fischer-Colbrie, R.; Hogue-Angeletti, R.; Winkler, H. Secretoneurin releases dopamine from rat striatal slices: A biological effect of a peptide derived from secretogranin II (chromogranin C). Neuroscience 1993, 54, 1-4. [CrossRef]

36. D'amico, M.A.; Ghinassi, B.; Izzicup, P.; Monzoli, L.; Di Baldassarre, A. Biological function and clinical relevance of chromogranin A and derived peptides. Endocr. Connect. 2014, 3, R45-R54. [CrossRef] [PubMed]

37. Mahata, S.K.; Corti, A. Chromogranin A and its fragments in cardiovascular, immunometabolic, and cancer regulation. Ann. N. Y. Acad. Sci. 2019, 1455, 34-58. [CrossRef]

38. Portel-Gomes, G.M.; Grimelius, L.; Johansson, H.; Wilander, E.; Stridsberg, M. Chromogranin A in human neuroendocrine tumors: An immunohistochemical study with region-specific antibodies. Am. J. Surg. Pathol. 2001, 25, 1261-1267. [CrossRef]

39. Strub, J.M.; Garcia-Sablone, P.; Lonning, K.; Taupenot, L.; Hubert, P.; Van Dorsselaer, A.; Aunis, D.; Metz-Boutigue, M.H. Processing of chromogranin B in bovine adrenal medulla. Identification of secretolytin, the endogenous C-terminal fragment of residues 614-626 with antibacterial activity. Eur. J. Biochem. 1995, 229, 356-368. [CrossRef]

40. Tasiemski, A.; Hammad, H.; Vandenbulcke, F.; Breton, C.; Bilfinger, T.J.; Pestel, J.; Salzet, M. Presence of chromogranin-derived antimicrobial peptides in plasma during coronary artery bypass surgery and evidence of an immune origin of these peptides. Blood 2002, 100, 553-559. [CrossRef]

41. Wiedermann, C.J.; Dunzendorfer, S.; Kähler, C.M.; Reinisch, N.; Schratzberger, P. Secretoneurin and neurogenic inflammation. Zhongguo Yao Li Xue Bao 1999, 20, 789-794. [PubMed]

42. Røsjø, H.; Stridsberg, M.; Florholmen, G.; Stensløkken, K.O.; Ottesen, A.H.; Sjaastad, I.; Husberg, C.; Dahl, M.B.; Øie, E.; Louch, W.E.; et al. Secretogranin II; a protein increased in the myocardium and circulation in heart failure with cardioprotective properties. PLoS ONE 2012, 7, e37401. [CrossRef]

43. Egger, M.; Schgoer, W.; Beer, A.G.; Jeschke, J.; Leierer, J.; Theurl, M.; Frauscher, S.; Tepper, O.M.; Niederwanger, A.; Ritsch, A.; et al. Hypoxia up-regulates the angiogenic cytokine secretoneurin via an HIF-1 $\alpha$ - and basic FGF-dependent pathway in muscle cells. FASEB J. 2007, 21, 2906-2917. [CrossRef]

44. O'Connor, D.T.; Bernstein, K.N. Radioimmunoassay of chromogranin A in plasma as a measure of exocytotic sympathoadrenal activity in normal subjects and patients with pheochromocytoma. N. Engl. J. Med. 1984, 311, 764-770. [CrossRef]

45. Tota, B.; Angelone, T.; Cerra, M.C. The surging role of chromogranin A in cardiovascular homeostasis. Front. Chem. 2014, 2, 64. [CrossRef]

46. Goetze, J.P.; Alehagen, U.; Flyvbjerg, A.; Rehfeld, J.F. Chromogranin A as a biomarker in cardiovascular disease. Biomark. Med. 2014, 8, 133-140. [CrossRef]

47. Herold, Z.; Herold, M.; Rosta, K.; Doleschall, M.; Somogyi, A. Lower serum chromogranin B level is associated with type 1 diabetes and with type 2 diabetes patients with intensive conservative insulin treatment. Diabetol. Metab. Syndr. 2020, 12, 61. [CrossRef]

48. O'Connor, D.T.; Cadman, P.E.; Smiley, C.; Salem, R.M.; Rao, F.; Smith, J.; Funk, S.D.; Mahata, S.K.; Mahata, M.; Wen, G.; et al. Pancreastatin: Multiple actions on human intermediary metabolism in vivo, variation in disease, and naturally occurring functional genetic polymorphism. J. Clin. Endocrinol. Metab. 2005, 90, 5414-5425. [CrossRef] [PubMed]

49. Sánchez-Margalet, V.; Lobón, J.A.; González, A.; Fernández-Soto, M.L.; Escobar-Jiménez, F.; Goberna, R. Increased plasma pancreastatin-like levels in gestational diabetes: Correlation with catecholamine levels. Diabetes Care 1998, 21, 1951-1954. [CrossRef] [PubMed]

50. Lu, L.; Wang, Y.N.; Li, M.C.; Wang, H.B.; Pu, L.J.; Niu, W.Q.; Meng, H.; Yang, E.L.; Zhang, R.Y.; Zhang, Q.; et al. Reduced serum levels of vasostatin-2, an anti-inflammatory peptide derived from chromogranin A, are associated with the presence and severity of coronary artery disease. Eur. Heart J. 2012, 33, 2297-2306. [CrossRef] [PubMed] 
51. Simunovic, M.; Supe-Domic, D.; Karin, Z.; Degoricija, M.; Paradzik, M.; Bozic, J.; Unic, I.; Skrabic, V. Serum catestatin concentrations are decreased in obese children and adolescents. Pediatr. Diabetes 2019, 20, 549-555. [CrossRef] [PubMed]

52. Tarantino, N.; Santoro, F.; Di Biase, L.; Di Terlizzi, V.; Vitale, E.; Barone, R.; Della Rocca, D.G.; De Leon, D.L.; Cruz, N.S.; Di Biase, M.; et al. Chromogranin-A serum levels in patients with takotsubo syndrome and ST elevation acute myocardial infarction. Int. J. Cardiol. 2020, 320, 12-17. [CrossRef] [PubMed]

53. Jansson, A.M.; Røsjø, H.; Omland, T.; Karlsson, T.; Hartford, M.; Flyvbjerg, A.; Caidahl, K. Prognostic value of circulating chromogranin A levels in acute coronary syndromes. Eur. Heart J. 2009, 30, 25-32. [CrossRef]

54. Estensen, M.E.; Hognestad, A.; Syversen, U.; Squire, I.; Ng, L.; Kjekshus, J.; Dickstein, K.; Omland, T. Prognostic value of plasma chromogranin A levels in patients with complicated myocardial infarction. Am. Heart J. 2006, 152, 927.e1-927.e6. [CrossRef] [PubMed]

55. Omland, T.; Dickstein, K.; Syversen, U. Association between plasma chromogranin A concentration and long-term mortality after myocardial infarction. Am. J. Med. 2003, 114, 25-30. [CrossRef]

56. Bachetti, T.; Ferrari Bardile, A.; Aloi, T.L.; Colombo, B.; Assi, E.; Savino, G.; Vercelli, A.; Colombo, R.; Corti, A. Plasma levels of vasostatin-1, a chromogranin A fragment, are associated with carotid artery maximum stenosis: A pilot study. Int. J. Cardiol. 2017, 236, 438-443. [CrossRef]

57. Chen, Y.; Wang, X.; Yang, C.; Su, X.; Yang, W.; Dai, Y.; Han, H.; Jiang, J.; Lu, L.; Wang, H.; et al. Decreased circulating catestatin levels are associated with coronary artery disease: The emerging anti-inflammatory role. Atherosclerosis 2019, 281, 78-88. [CrossRef]

58. Xu, W.; Yu, H.; Wu, H.; Li, S.; Chen, B.; Gao, W. Plasma catestatin in patients with acute coronary syndrome. Cardiology 2017, 136, 164-169. [CrossRef]

59. Pan, W.Q.; He, Y.H.; Su, Q.; Yang, J.; Fang, Y.H.; Ding, F.H.; Yan, X.X.; Liu, Z.H.; Wang, X.Q.; Yang, K.; et al. Association of decreased serum vasostatin-2 level with ischemic chronic heart failure and with MACE in 3-year follow-up: Vasostatin-2 prevents heart failure in myocardial infarction rats. Int. J. Cardiol. 2016, 221, 1-11. [CrossRef]

60. Liu, L.; Ding, W.; Zhao, F.; Shi, L.; Pang, Y.; Tang, C. Plasma levels and potential roles of catestatin in patients with coronary heart disease. Scand. Cardiovasc. J. 2013, 47, 217-224. [CrossRef] [PubMed]

61. Zhu, D.; Xie, H.; Wang, X.; Liang, Y.; Yu, H.; Gao, W. Correlation of plasma catestatin level and the prognosis of patients with acute myocardial infarction. PLOS ONE 2015, 10, e0122993. [CrossRef] [PubMed]

62. Xu, W.; Yu, H.; Li, W.; Gao, W.; Guo, L.; Wang, G. Plasma catestatin: A useful biomarker for coronary collateral development with chronic myocardial ischemia. PLoS ONE 2016, 11, e0149062. [CrossRef]

63. Zhu, D.; Xie, H.; Wang, X.; Liang, Y.; Yu, H.; Gao, W. Catestatin-A novel predictor of left ventricular remodeling after acute myocardial infarction. Sci. Rep. 2017, 7, 44168. [CrossRef] [PubMed]

64. Meng, L.; Wang, J.; Ding, W.H.; Han, P.; Yang, Y.; Qi, L.T.; Zhang, B.W. Plasma catestatin level in patients with acute myocardial infarction and its correlation with ventricular remodelling. Postgrad. Med. J. 2013, 89, 193-196. [CrossRef]

65. Takiyyuddin, M.A.; Parmer, R.J.; Kailasam, M.T.; Cervenka, J.H.; Kennedy, B.; Ziegler, M.G.; Lin, M.C.; Li, J.; Grim, C.E.; Wright, F.A. Chromogranin A in human hypertension. Influence of heredity. Hypertension 1995, 26, 213-220. [CrossRef] [PubMed]

66. Durakoğlugil, M.E.; Ayaz, T.; Kocaman, S.A.; Kırbaş, A.; Durakoğlugil, T.; Erdoğan, T.; Çetin, M.; Şahin, O.Z.; Çiçek, Y. The relationship of plasma catestatin concentrations with metabolic and vascular parameters in untreated hypertensive patients: Influence on high-density lipoprotein cholesterol. Anatol. J. Cardiol. 2015, 15, 577-585. [CrossRef]

67. Sánchez-Margalet, V.; Valle, M.; Lobón, J.A.; Maldonado, A.; Escobar-Jimenez, F.; Oliván, J.; Pérez-Cano, R.; Goberna, R. Increased plasma pancreastatin-like immunoreactivity levels in non-obese patients with essential hypertension. J. Hypertens. 1995, 13, 251-258.

68. Ceconi, C.; Ferrari, R.; Bachetti, T.; Opasich, C.; Volterrani, M.; Colombo, B.; Parrinello, G.; Corti, A. Chromogranin A in heart failure; a novel neurohumoral factor and a predictor for mortality. Eur. Heart J. 2002, 23, 967-974. [CrossRef]

69. Røsjø, H.; Husberg, C.; Dahl, M.B.; Stridsberg, M.; Sjaastad, I.; Finsen, A.V.; Carlson, C.R.; Oie, E.; Omland, T.; Christensen, G. Chromogranin B in heart failure: A putative cardiac biomarker expressed in the failing myocardium. Circ. Heart Fail. 2010, 3, 503-511. [CrossRef]

70. Liu, L.; Ding, W.; Li, R.; Ye, X.; Zhao, J.; Jiang, J.; Meng, L.; Wang, J.; Chu, S.; Han, X.; et al. Plasma levels and diagnostic value of catestatin in patients with heart failure. Peptides 2013, 46, 20-25. [CrossRef]

71. Dobson, R.; Burgess, M.I.; Banks, M.; Pritchard, D.M.; Vora, J.; Valle, J.W.; Wong, C.; Chadwick, C.; George, K.; Keevil, B.; et al. The association of a panel of biomarkers with the presence and severity of carcinoid heart disease: A cross-sectional study. PLoS ONE 2013, 8, e73679. [CrossRef]

72. Pieroni, M.; Corti, A.; Tota, B.; Curnis, F.; Angelone, T.; Colombo, B.; Cerra, M.C.; Bellocci, F.; Crea, F.; Maseri, A. Myocardial production of chromogranin A in human heart: A new regulatory peptide of cardiac function. Eur. Heart J. 2007, 28, 1117-1127. [CrossRef] [PubMed]

73. Tombetti, E.; Colombo, B.; Di Chio, M.C.; Sartorelli, S.; Papa, M.; Salerno, A.; Bozzolo, E.P.; Tombolini, E.; Benedetti, G.; Godi, C.; et al. Chromogranin-A production and fragmentation in patients with Takayasu arteritis. Arthritis Res. Ther. 2016, 18, 187. [CrossRef] 
74. Ottesen, A.H.; Louch, W.E.; Carlson, C.R.; Landsverk, O.J.B.; Kurola, J.; Johansen, R.F.; Moe, M.K.; Aronsen, J.M.; Høiseth, A.D.; Jarstadmarken, H.; et al. Secretoneurin is a novel prognostic cardiovascular biomarker associated with cardiomyocyte calcium handling. J. Am. Coll. Cardiol. 2015, 65, 339-351. [CrossRef] [PubMed]

75. Brynildsen, J.; Myhre, P.L.; Lyngbakken, M.N.; Klaeboe, L.G.; Stridsberg, M.; Christensen, G.; Edvardsen, T.; Omland, T.; Røsjø, H. Circulating secretoneurin concentrations in patients with moderate to severe aortic stenosis. Clin. Biochem. 2019, 71, 17-23. [CrossRef]

76. Brynildsen, J.; Petäjä, L.; Myhre, P.L.; Lyngbakken, M.N.; Nygård, S.; Stridsberg, M.; Christensen, G.; Ottesen, A.H.; Pettilä, V.; Omland, T.; et al. Circulating secretoneurin concentrations after cardiac surgery: Data from the FINNish Acute Kidney Injury Heart Study. Crit. Care Med. 2019, 47, e412-e419. [CrossRef]

77. Soell, M.; Feki, A.; Hannig, M.; Sano, H.; Pinget, M.; Selimovic, D. Chromogranin A detection in saliva of type 2 diabetes patients. Bosn. J. Basic Med. Sci. 2010, 10, 2-8. [CrossRef]

78. Kogawa, E.M.; Grisi, D.C.; Falcão, D.P.; Amorim, I.A.; Rezende, T.M.; da Silva, I.C.; Silva, O.N.; Franco, O.L.; de Amorim, R.F. Impact of glycemic control on oral health status in type 2 diabetes individuals and its association with salivary and plasma levels of chromogranin A. Arch. Oral Biol. 2016, 62, 10-19. [CrossRef]

79. Fournier, I.; Gaucher, D.; Chich, J.F.; Bach, C.; Shooshtarizadeh, P.; Picaud, S.; Bourcier, T.; Speeg-Schatz, C.; Strub, J.M.; Van Dorsselaer, A.; et al. Processing of chromogranins/secretogranin in patients with diabetic retinopathy. Regul. Pept. 2011, 167, 118-124. [CrossRef] [PubMed]

80. Mahata, S.K.; Kiranmayi, M.; Mahapatra, N.R. Catestatin: A mster regulation of cardiovascular functions. Curr. Med. Chem. 2018, 25, 1352-1374. [CrossRef] [PubMed]

81. Fung, M.M.; Salem, R.M.; Mehtani, P.; Thomas, B.; Lu, C.F.; Perez, B.; Rao, F.; Stridsberg, M.; Ziegler, M.G.; Mahata, S.K.; et al. Direct vasoactive effects of the chromogranin A (CHGA) peptide catestatin in humans in vivo. Clin. Exp. Hypertens. 2010, 32, 278-287. [CrossRef]

82. Aardal, S.; Helle, K.B.; Elsayed, S.; Reed, R.K.; Serck-Hanssen, S. Vasostatins, comprising the N-terminal domain of chromogranin A, suppress tension in isolated human blood vessel segments. J. Neuroendocrinol. 1993, 5, 405-412. [CrossRef] [PubMed]

83. Aardal, S.; Galindo, E.; Aunis, D.; Helle, K.B. Human chromostatin inhibits endothelin-1-induced contractures in human blood vessels. Regul. Pept. 1993, 47, 25-32. [CrossRef]

84. González-Yanes, C.; Santos-Alvarez, J.; Sánchez-Margalet, V. Pancreastatin, a chromogranin A-derived peptide, activates Galpha(16) and phospholipase C-beta(2) by interacting with specific receptors in rat heartmembranes. Cell Signal. 2001, 13, 43-49. [CrossRef]

85. Lugardon, K.; Chasserot-Golaz, S.; Kieffer, A.E.; Maget-Dana, R.; Nullans, G.; Kieffer, B.; Aunis, D.; Metz-Boutigue, M.H. Structural and biological characterization of chromofungin, the antifungal chromogranin A-(47-66)-derived peptide. J. Biol. Chem. 2001, 276, 35875-35882. [CrossRef] [PubMed]

86. Strub, J.M.; Sorokine, O.; van Dorsselaer, A.; Aunis, D.; Metz-Boutigue, M.H. Phosphorylation and O-glycosylation sites of bovine chromogarnin A from adrenal medullary chromaffin granules and their relationship with biological activities. J. Biol. Chem. 1997, 272, 11928-11936. [CrossRef]

87. Tota, B.; Gentile, S.; Pasqua, T.; Bassino, E.; Koshimizu, H.; Cawley, N.X.; Cerra, M.C.; Loh, Y.P.; Angelone, T. The novel chromogranin A-derived serpinin and pyroglutaminated serpininpeptides are positive cardiac $\beta$-adrenergic-like inotropes. FASEB J. 2012, 26, 2888-2898. [CrossRef] [PubMed]

88. Rocca, C.; De Bartolo, A.; Grande, F.; Rizzuti, B.; Pasqua, T.; Giordano, F.; Granieri, M.C.; Occhiuzzi, M.A.; Garofalo, A.; Amodio, N.; et al. Cateslytin abrogates lipopolysaccharide-induced cardiomyocyte injury by reducing inflammation and oxidative stress through toll like receptor 4 interaction. Int. Immunopharmacol. 2021, 94, 107487. [CrossRef]

89. Theurl, M.; Schgoer, W.; Albrecht, K.; Jeschke, J.; Egger, M.; Beer, A.G.; Vasiljevic, D.; Rong, S.; Wolf, A.M.; Bahlmann, F.H.; et al. The neuropeptide catestatin acts as a novel angiogenic cytokine via a basic fibroblast growth factor-dependent mechanism. Circ. Res. 2010, 107, 1326-1335. [CrossRef]

90. Fischer-Colbrie, R.; Kirchmair, R.; Kähler, C.M.; Wiedermann, C.J.; Saria, A. Secretoneurin: A new player in angiogenesis and chemotaxis linking nerves, blood vessels and the immune system. Curr. Protein Pept. Sci. 2005, 6, 373-385. [CrossRef] [PubMed]

91. Veschini, L.; Crippa, L.; Dondossola, E.; Doglioni, C.; Corti, A.; Ferrero, E. The vasostatin-1 fragment of chromogranin A preserves a quiescent phenotype in hypoxia-driven endothelial cells and regulates tumor neovascularization. FASEB J. 2011, 25, 3906-3914. [CrossRef] [PubMed]

92. Maestroni, S.; Maestroni, A.; Ceglia, S.; Tremolada, G.; Mancino, M.; Sacchi, A.; Lattanzio, R.; Zucchiatti, I.; Corti, A.; Bandello, F.; et al. Effect of chromogranin A-derived vasostatin-1 on laser-induced choroidal neovascularization in the mouse. Acta Ophthalmol. 2015, 93, e218-e222. [CrossRef]

93. Albrecht-Schgoer, K.; Schgoer, W.; Holfeld, J.; Theurl, M.; Wiedemann, D.; Steger, C.; Gupta, R.; Semsroth, S.; Fischer-Colbrie, R.; Beer, A.G.; et al. The angiogenic factor secretoneurin induces coronary angiogenesis in a model of myocardial infarction by stimulation of vascular endothelial growth factor signaling in endothelial cells. Circulation 2012, 126, 2491-2501. [CrossRef] [PubMed]

94. Mundi, S.; Massaro, M.; Scoditti, E.; Carluccio, M.A.; van Hinsbergh, V.W.M.; Iruela-Arispe, M.L.; De Caterina, R. Endothelial permeability, LDL deposition, and cardiovascular risk factors-A review. Cardiovasc. Res. 2018, 114, 35-52. [CrossRef] 
95. Obikane, H.; Abiko, Y.; Ueno, H.; Kusumi, Y.; Esumi, M.; Mitsumata, M. Effect of endothelial cell proliferation on atherogenesis: A role of $\mathrm{p} 21^{\mathrm{Sdi} / \mathrm{Cip} / \text { Waf1 }}$ in monocyte adhesion to endothelial cells. Atherosclerosis 2010, 212, 116-122. [CrossRef]

96. Ferreno, E.; Scabini, S.; Magni, E.; Foglieni, C.; Belloni, D.; Colombo, B.; Curnis, F.; Villa, A.; Ferrero, M.E.; Corti, A. Chromogranin A protects vessels against tumor necrosis factor $\alpha$-induced vascular leakage. FASEB J. 2004, 18, 554-556. [CrossRef]

97. Helle, K.B.; Metz-Boutigue, M.H.; Cerra, M.C.; Angelone, T. Chromogranins: From discovery to current times. Pflugers Arch. 2018, 470, 143-154. [CrossRef] [PubMed]

98. Luo, L.; Liu, S.; Zhang, D.; Wei, F.; Gu, N.; Zeng, Y.; Chen, X.; Xu, S.; Liu, S.; Xiang, T. Chromogranin A (CGA)-derived polypeptide $\left(\mathrm{CGA}_{47-66}\right)$ inhibits TNF- $\alpha$-induced vascular endothelial hyper-permeability through SOC-related $\mathrm{Ca}^{2+}$ signaling. Peptides 2020, 131, 170297. [CrossRef]

99. Blois, A.; Srebro, B.; Mandalà, M.; Corti, A.; Helle, K.B.; Serck-Hanssen, G. The chromogranin A peptide vasostatin-I inhibits gap formation and signal transduction mediated by inflammatory agents in cultured bovine pulmonary and coronary arterial endothelial cells. Regul. Pept. 2006, 135, 78-84. [CrossRef] [PubMed]

100. Belloni, D.; Scabini, S.; Foglieni, C.; Veschini, L.; Giazzon, A.; Colombo, B.; Fulgenzi, A.; Helle, K.B.; Ferrero, M.E.; Corti, A.; et al. The vasostatin-I fragment of chromogranin A inhibits VEGF-induced endothelial proliferation and migration. FASEB J. 2007, 21, 3052-3062. [CrossRef]

101. Helle, K.B. Regulatory peptides from chromogranin A and secretogranin II: Putative modulators of cells and tissues involved in inflammatory conditions. Regul. Pept. 2010, 165, 45-51. [CrossRef] [PubMed]

102. Schgoer, W.; Theurl, M.; Jeschke, J.; Beer, A.G.; Albrecht, K.; Gander, R.; Rong, S.; Vasiljevic, D.; Egger, M.; Wolf, A.M.; et al. Gene therapy with the angiogenic cytokine secretoneurin induces therapeutic angiogenesis by a nitric oxide-dependent mechanism. Circ. Res. 2009, 105, 994-1002. [CrossRef] [PubMed]

103. Kähler, C.M.; Kirchmair, R.; Kaufmann, G.; Kähler, S.T.; Reinisch, N.; Fischer-Colbrie, R.; Hongue-Angeletti, R.; Winkler, H.; Wiedermann, C.J. Inhibition of proliferation and stimulation of migration of endothelial cells by secretoneurin in vitro. Arterioscler. Thromb. Vasc. Biol. 1997, 17, 932-939. [CrossRef] [PubMed]

104. Kähler, C.M.; Kaufmann, G.; Kähler, S.T.; Wiedermann, C.J. The neuropeptide secretoneurin stimulates adhesion of human monocytes to arterial and venous endothelial cells in vitro. Regul. Pept. 2002, 110, 65-73. [CrossRef]

105. Chan, C.K.; Vanhoutte, P.M. Secretoneurin facilitates endothelium-dependent relaxations in porcine coronary arteries. Am. J. Physiol. Heart Circ. Physiol. 2011, 300, H1159-H1165. [CrossRef]

106. Watanabe, R.; Watanabe, H.; Takahashi, Y.; Kojima, M.; Konii, H.; Watanabe, K.; Shirai, R.; Sato, K.; Matsuyama, T.; Ishibashi-Ueda, H.; et al. Atheroprotective effects of tumor necrosis factor-stimulated gene-6. JACC Basic Transl. Sci. 2016, 6, 494-509. [CrossRef]

107. Egger, M.; Beer, A.G.; Theurl, M.; Schgoer, W.; Hotter, B.; Tatarczyk, T. Monocyte migration: A novel effect and signaling pathways of catestatin. Eur. J. Pharmacol. 2008, 598, 104-111. [CrossRef]

108. Reinisch, N.; Kirchmair, R.; Kähler, C.M.; Hogue-Angeletti, R.; Fischer-Colbrie, R.; Winkler, H.; Wiedermann, C.J. Attraction of human monocytes by the neuropeptide secretoneurin. FEBS Lett. 1993, 334, 41-44. [CrossRef]

109. Ying, W.; Tang, K.; Avolio, E.; Schilling, J.M.; Pasqua, T.; Liu, M.A.; Cheng, H.; Gao, H.; Zhang, J.; Mahata, S.; et al. Immunosuppression of macrophages underlies the cardioprotective effects of CST (Catestatin). Hypertension 2021, 77, 1670-1682. [CrossRef]

110. Adiguzel, E.; Ahmad, P.J.; Franco, C.; Bendeck, M.P. Collagens in the progression and complications of atherosclerosis. Vasc. Med. 2009, 14, 73-89. [CrossRef]

111. Wagenseil, J.E.; Mecham, R.P. Elastin in large artery stiffness and hypertension. J. Cardiovasc. Transl. Res. 2012, 5, 264-273. [CrossRef] [PubMed]

112. Hou, J.; Xue, X.; Li, J. Vasostatin-2 inhibits cell proliferation and adhesion in vascular smooth muscle cells, which are associated with the progression of atherosclerosis. Biochem. Biophys. Res. Commun. 2016, 469, 948-953. [CrossRef] [PubMed]

113. Guo, X.; Zhou, C.; Sun, N. The neuropeptide catestatin promotes vascular smooth muscle cell proliferation through the Ca ${ }^{2+}$ calcineurin-NFAT signaling pathway. Biochem. Biophys. Res. Commun. 2011, 407, 807-812. [CrossRef]

114. Kähler, C.M.; Schratzberger, P.; Wiedermann, C.J. Response of vascular smooth muscle cells to the neuropeptide secretoneurin. A functional role for migration and proliferation in vitro. Arterioscler. Thromb. Vasc. Biol. 1997, 17, 2029-2035. [CrossRef]

115. Liu, W.; Wang, F.; Zhao, M.; Fan, Y.; Cai, W.; Luo, M. The neuropeptide secretoneurin exerts a direct effect on arteriogenesis in vivo and in vitro. Anat. Rec. 2018, 301, 1917-1927. [CrossRef]

116. Bourebaba, Y.; Mularczyk, M.; Marycz, K.; Bourebaba, L. Catestatin peptide of chromogranin A as a potential new target for several risk factors management in the course of metabolic syndrome. Biomed. Pharmacother. 2020, 134, 111113. [CrossRef]

117. Gayen, J.R.; Saberi, M.; Schenk, S.; Biswas, N.; Vaingankar, S.M.; Cheung, W.W.; Najjar, S.M.; O'Connor, D.T.; Bandyopadhyay, G.; Mahata, S.K. A novel pathway of insulin sensistivity in chromogranin A null mice: A crucial role for pancreastatin in glucose homeostasis. J. Biol. Chem. 2009, 284, 28498-28509. [CrossRef] [PubMed]

118. Bandyopadhyay, G.K.; Mahata, S.K. Chromogranin A regulation of obesity and peripheral insulin sensitivity. Front. Endocrinol. 2017, 8, 20. [CrossRef]

119. Pasqua, T.; Corti, A.; Gentile, S.; Pochini, L.; Bianco, M.; Metz-Boutigue, M.H.; Carmela, M.; Tota, B.; Angelone, T. Full-length human chromogranin-A cardioactivity: Myocardial, coronary, and stimulus-induced processing evidence in normotensive and hypertensive male rat hearts. Endocrinology 2013, 154, 3353-3365. [CrossRef] 
120. Penna, C.; Alloatti, G.; Gallo, M.P.; Cerra, M.C.; Levi, R.; Tullio, F.; Bassino, E.; Dolgetta, S.; Mahata, S.K.; Tota, B.; et al. Catestatin improves post-ischemic left ventricular function and decreases ischemia/reperfusion injury in heart. Cell. Mol. Neurobiol. 2010, 30, 1171-1179. [CrossRef]

121. Cappello, S.; Angelone, T.; Tota, B.; Pagliaro, P.; Penna, C.; Rastaldo, R.; Corti, A.; Losano, G.; Cerra, M.C. Human recombinant chromogranin A-derived vasostatin-1 mimics preconditioning via an adenosine/nitric oxide signaling mechanism. Am. J. Physiol. Heart Circ. Physiol. 2007, 293, H719-H727. [CrossRef] [PubMed]

122. Filice, E.; Pasqua, T.; Quintieri, A.M.; Cantafio, P.; Scavello, F.; Amodio, N.; Cerra, M.C.; Marban, C.; Schneider, F.; Metz-Boutigue, M.-H.; et al. Chromofungin, CgA 47-66 -derived peptide, produces basal cardiac effects and postconditioning cardioprotective action during ischemia/reperfusion injury. Peptides 2015, 71, 40-48. [CrossRef]

123. Pasqua, T.; Tota, B.; Penna, C.; Corti, A.; Cerra, M.C.; Loh, Y.P.; Angelone, T. pGlu-serpinin protects the normotensive and hypertensive heart from ischemic injury. J. Endocrinol. 2015, 227, 167-178. [CrossRef]

124. Theurl, M.; Schgoer, W.; Albrecht-Schgoer, K.; Lener, D.; Wolf, D.; Wolf, M.; Demetz, E.; Tymoszuk, P.; Tancevski, I.; FischerColbrie, R.; et al. Secretoneurin gene therapy improves hind limb and cardiac ischaemia in Apo $\mathrm{E}^{-/-}$mice without influencing systemic atherosclerosis. Cardiovasc. Res. 2015, 105, 96-106. [CrossRef]

125. Albrecht-Schgoer, K.; Barthelmes, J.; Schgoer, W.; Theurl, M.; Nardin, I.; Lener, D.; Gutmann, C.; Dünnhaupt, S.; BernkopSchnürch, A.; Kirchmair, R. Nanoparticular delivery system for a secretoneurin derivative induces angiogenesis in a hind limb ischemia model. J. Control. Release 2017, 250, 1-8. [CrossRef]

126. Schgoer, W.; Theurl, M.; Albrecht-Schgoer, K.; Jonach, V.; Koller, B.; Lener, D.; Franz, W.M.; Kirchmair, R. Secretoneurin gene therapy improves blood flow in an ischemia model in type 1 diabetic mice by enhancing therapeutic neovascularization. PLoS ONE 2013, 8, e74029. [CrossRef] [PubMed]

127. Theurl, M.; Lener, D.; Albrecht-Schgoer, K.; Beer, A.; Schgoer, W.; Liu, Y.; Stanzl, U.; Fischer-Colbrie, R.; Kirchmair, R. Gene therapy with the angiogenic neuropeptide secretoneurin ameliorates experimental diabetic neuropathy. FASEB J. 2018, 32, 4815-4823. [CrossRef] [PubMed]

128. Chen, H.L.; Liu, Y.; Jiang, W.; Wang, X.X.; Yuan, G.L.; Zhao, Y.L.; Yu, C. Secretoneurin suppresses cardiac hypertrophy through suppression of oxidant stress. Eur. J. Pharmacol. 2018, 822, 13-24. [CrossRef]

129. Posod, A.; Wechselberger, K.; Stanika, R.I.; Obermair, G.J.; Wegleiter, K.; Huber, E.; Urbanek, M.; Kiechl-Kohlendorfer, U.; Griesmaier, E. Administration of secretoneurin is protective in hypoxic-ischemic neonatal brain injury predominantly in the hypoxic-only hemisphere. Neuroscience 2017, 352, 88-96. [CrossRef] [PubMed]

130. Shyu, W.C.; Lin, S.Z.; Chiang, M.F.; Chen, D.C.; Su, C.Y.; Wang, H.J.; Liu, R.S.; Tsai, C.H.; Li, H. Secretoneurin promotes neuroprotection and neuronal plasticity via the Jak2/Stat3 pathway in murine models of stroke. J. Clin. Investig. 2008, 118, 133-148. [CrossRef] [PubMed]

131. Ying, W.; Mahata, S.; Bandyopadhyay, G.K.; Zhou, Z.; Wollam, J.; Vu, J.; Mayoral, R.; Chi, N.W.; Webster, N.J.G.; Corti, A.; et al. Catestatin inhibits obesity-induced macrophage infiltration and inflammation in the liver and suppresses hepatic glucose production, leading to improved insulin sensitivity. Diabetes 2018, 67, 841-848. [CrossRef] [PubMed]

132. Delong, T.; Baker, R.L.; He, J.; Barbour, G.; Bradley, B.; Haskins, K. Diabetogenic T-cell clones recognize an altered peptide of chromogranin A. Diabetes 2012, 61, 3239-3246. [CrossRef] [PubMed]

133. Li, Y.; Zhou, L.; Li, Y.; Zhang, J.; Guo, B.; Meng, G.; Chen, X.; Zheng, Q.; Zhang, L.; Zhang, M.; et al. Identification of autoreactive CD8+ T cell responses targeting chromogranin A in humanized NOD mice and type 1 diabetes patients. Clin. Immunol. 2015, 159, 63-71. [CrossRef]

134. Nikoopour, E.; Sandrock, C.; Huszarik, K.; Krougly, O.; Lee-Chan, E.; Masteller, E.L.; Bluestone, J.A.; Singh, B. Cutting edge: Vasostatin-1-derived peptide ChgA29-42 is an antigenic epitope of diabetogenic BDC2.5 T cells in nonobese diabetic mice. J. Immunol. 2011, 186, 3831-3835. [CrossRef]

135. Valicherla, G.R.; Hossain, Z.; Mahata, S.K.; Gayen, J.R. Pancreastatin is an endogenous peptide that regulates glucose homeostasis. Physiol. Genomics 2013, 45, 1060-1071. [CrossRef]

136. González-Yanes, C.; Sánchez-Magalet, V. Pancreastatin, a chromogranin-A-derived peptide, inhibits insulin-stimulated glycogen synthesis by activating GSK-3 in rat adipocytes. Biochem. Biophys. Res. Commun. 2001, 289, 282-287. [CrossRef]

137. Gupta, A.P.; Syed, A.A.; Garg, R.; Goand, U.K.; Singh, P.; Riyazuddin, M.; Valicherla, G.R.; Husain, A.; Gayen, J.R. Pancreastatin inhibitor PSTi8 attenuates hyperinsulinemia induced obesity and inflammation mediated insulin resistance via MAPK/NOX3JNK pathway. Eur. J. Pharmacol. 2019, 864, 172723. [CrossRef]

138. Bandyopadhyay, G.K.; Lu, M.; Avolio, E.; Siddiqui, J.A.; Gayen, J.R.; Wollam, J.; Vu, C.U.; Chi, N.W.; O’Connor, D.T.; Mahata, S.K. Pancreastatin-dependent inflammatory signaling mediates obesity-induced insulin resistance. Diabetes 2015, 64, 104-116. [CrossRef]

139. Zagórowicz, E.; Bak, M.; Siemińska, J.; Muszyński, J. Pancreastatin secretion stimulation in healthy volunteers. Pol. Arch. Med. Wewn. 2002, 108, 1185-1191. [PubMed]

140. Cadman, P.E.; Rao, F.; Mahata, S.K.; O'Connor, D.T. Studies of the dysglycemic peptide, pancreastatin, using a human forearm model. Ann. N. Y. Acad. Sci. 2002, 971, 528-529. [CrossRef] [PubMed]

141. Siegel, E.G.; Gallwitz, B.; Fölsch, U.R.; Schmidt, W.E. Effect of human pancreastatin peptide (hP-16) on oral glucose tolerance in man. Exp. Clin. Endocrinol. Diabetes 1998, 106, 178-182. [CrossRef] [PubMed] 
142. Valicherla, G.R.; Gupta, A.P.; Hossain, Z.; Riyazuddin, M.; Syed, A.A.; Husain, A.; Lahiri, S.; Dave, K.M.; Gayen, J.R. Pancreastatin inhibitor, PSTi8 ameliorates metabolic health by modulating AKT/GSK-3 $\beta$ and PKC $\lambda / \zeta / S R E B P 1 c$ pathways in high fat diet induced insulin resistance in peri-/post-menopausal rats. Peptides 2019, 120, 170147. [CrossRef] [PubMed]

143. Gupta, A.P.; Garg, R.; Singh, P.; Goand, U.K.; Syed, A.A.; Valicherla, G.R.; Riyazuddin, M.; Mugale, M.N.; Gayen, J.R. Pancreastatin inhibitor PSTi8 protects the obesity associated skeletal muscle insulin resistance in diet induced streptozotocin-treated diabetic mice. Eur. J. Pharmacol. 2020, 881, 173204. [CrossRef] [PubMed]

144. Gupta, A.P.; Singh, P.; Garg, R.; Valicherla, G.R.; Riyazuddin, M.; Syed, A.A.; Hossain, Z.; Gayen, J.R. Pancreastatin inhibitor activates AMPK pathway via GPR78 and ameliorates dexamethasone induced fatty liver disease in C57BL/6 mice. Biomed. Pharmacother. 2019, 116, 108959. [CrossRef] [PubMed] 